\title{
Correction to: The impact of helicobacter pylori eradication on platelet counts of adult patients with idiopathic thrombocytopenic purpura
}

Sara Aljarad ${ }^{1}$, Ahmad Alhamid ${ }^{3}$, Ahmad Sankari Tarabishi $^{3}$, Ameen Suliman $^{1}$ and Ziad Aljarad $^{2^{*}}$

\section{Correction to: BMC Hematol (2018) 18: 28 \\ https://doi.org/10.1186/s12878-018-0119-y}

In the original version of this article [1], published on 20 September 2018, there was an error in the author name of Dr. Sankari Tarabishi.

Originally the author name was published/cited as:

Tarabishi, AS.

The correct name is:

Sankari Tarabishi, A.

The correct name and citation is available via this correction article.

\section{Author details}

'Department of Hematology, Al Mouwasat University Hospital, Damascus,

Syria. ${ }^{2}$ Department of Gastroenterology, Aleppo University Hospital, Aleppo,

Syria. ${ }^{3}$ Medical student, Faculty of Medicine, University of Aleppo, Aleppo,

Syria.

Received: 24 May 2019 Accepted: 24 May 2019

Published online: 30 May 2019

\section{Reference}

1. Aljarad S, Alhamid A, Sankari Tarabishi A, et al. The impact of helicobacter

pylori eradication on platelet counts of adult patients with idiopathic

thrombocytopenic purpura. BMC Hematol. 2018;18:28. https://doi.org/10.

1186/s12878-018-0119-y.

\footnotetext{
* Correspondence: dr.ziad-aljarad@hotmail.com

${ }^{2}$ Department of Gastroenterology, Aleppo University Hospital, Aleppo, Syria

Full list of author information is available at the end of the article
}

(c) The Author(s). 2019 Open Access This article is distributed under the terms of the Creative Commons Attribution 4.0 International License (http://creativecommons.org/licenses/by/4.0/), which permits unrestricted use, distribution, and reproduction in any medium, provided you give appropriate credit to the original author(s) and the source, provide a link to the Creative Commons license, and indicate if changes were made. The Creative Commons Public Domain Dedication waiver (http://creativecommons.org/publicdomain/zero/1.0/) applies to the data made available in this article, unless otherwise stated. 